\title{
The Subterranean Fauna Associated with the Blind Palaemonid Prawn Typhlocaris galilea Calman ${ }^{1)}$
}

\author{
Moshe Tsurnamal and Francis Dov Por 2)
}

With plate 69 (1)

Typhlocaris galilea Calman is an endemic species. Its only known locality is the spring of En-Nur, a warm sulphur spring at Tabgha, on the northern shore of Lake Tiberias in Israel (Figure 1a).

The spring of En-Nur (Temperature, 29,5 C; $2300-3000 \mathrm{mg} \mathrm{Cl} /$ lit.) flows into an octagonal pool formerly known as Birket 'Ali-Ed-Dhaher'. This pool is the type locality of Typhlocaris galilea (Calman, 1909; Annandale and Kemp, 1913). A small population of this blind prawn can indeed be observed in the pool - although its main population is found in the subterranean tract of En-Nur (Tsurnamal, in preparation).

Irreversible hydrological changes are expected to occur in the springs of Tabgha as a result of the use of Lake Tiberias as a main water reservoir for the country. Intensive research has therefore been undertaken in the pool and the spring of En-Nur during the last three years. Although attention has been devoted mainly to the elucidation of the biology of Typhlocaris, additional hypogeic organisms were discovered, in the subterranean tract of the spring.

\section{The Habitat}

The subterranean habitat under investigation (Figure $1 \mathrm{~b}$ ) consists of a $7 \mathrm{~m}$ long narrow inclined cave ("tunnel") trough which the water ascends to the octagonal pool. The "tunnel" widens into a rather oval cavity ("hall") approximately $7.5 \mathrm{~m}$. long , $4.5 \mathrm{~m}$. wide and $2.5 \mathrm{~m}$. high. The bottom of the "hall" lies $5 \mathrm{~m}$. beneath the bottom of the octagonal pool and is composed mainly of a yellow-brown sediment, rich in small gastropod shells and detritic material. Like the "tunnel" the "hall" is entirely filled with water. An over $8 \mathrm{~m}$. deep vertical "shaft" opens in the north-west part of the "hall's" floor. At its deepest end it narrows to such an extent that it makes diving

1) This research has been partly supported by the "Mekoroth" Water Company of Israel.

2) Department of Zoology, Hebrew University of Jerusalem, Israel. 
through extremely difficult. Some narrow horizontal fissures open in the karstic rock at the extreme end of the "shaft" conducting warm water into the "shaft" in a rapid flow up.

\section{Methods}

The subterranean habitat was explored several times during all seasons of the year, by SCUBA equipment. Underwater observations and collecting were carried out by the aid of powerfull underwater electric torches and by hand nets (silk mesh of $0.2 \mathrm{~mm}$ ). Samples of bottom sediments and of organisms from the rocky walls and ceiling of the aquifer were placed into small polyethylene bags or into glass jars and were brought to the surface.

Some bottom sediments were stirred up by the movements of the divers in the aquifer, and specially in the "hall", and were partly swept out by the outflowing water. Most of that material, however, was collected by a special "plankton net" (iron frame $=1 \times 0.6 \mathrm{~m}$; lenght of silk mesh cone $-1.7 \mathrm{~m}$; mesh $-0.2 \mathrm{~mm}$ ) fixed in front of the outlet of the spring. In some instances the above mentioned hand nets were also used.

\section{Observations and Collected Material}

Most of the rocky surfaces of the subterranean cavities as well as some of the stones and rocks on the bottom are covered by a thin bacterial film. Tufts of filamentous sulphur bacteria (and it seems that also of some pigmentless Cyanophyta) protrude out of fissures and crevices in the rocky walls, and ceiling. They were also found attached to particles on the yellow detritic sediment on the bottom of the "hall". This flora seems to form the main trophic basis for the subterranean biocoenosis as the gastropods, small crustaceans, nematods and oligochaets, feed on the bacteria (algae?); the blind prawn in turn feeds mainly on oligochaets.

Many pigmentless gastropods of the genus Theodoxus (a variety of $T$. jordani Sowerby?) were found attached to, or crawling slowly on the walls and ceiling of the cavities. This is the first Theodoxus reported from subterranean waters. The Theodoxus is more abundant in crevices - especially in those of the "tunnel", and is always restricted to the rocky substrate. The snail is unable to move on soft sediments and an accidental fall to the bottom may cause its death.

Bythinella sp., a second, much smaller, pigmentless gastropod is also found crawling on the walls but it is more common on the soft bottom of the "hall" where the accumulation of its empty and broken shells has become one of the main components of the sediment. Scattered specimens of a dwarf variety of the black pigmented gastropod Melanopsis praemorsa L. 
may be found among the above mentioned snails. This gastropod is also common in the water of the octagonal pool. The shells of the "dwarf" Melanopsis gastropods are only 6-9 mm long as compared with the 15 to $20 \mathrm{~mm}$ shells of "normal" specimens collected in other springs nearby.

The "dwarf" Melanopsis praemorsa is most common on the soft bottom of the "hall" but its specimens can also be found on rocky surfaces. Because of their dark shells the Melanopsis snails are the most conspicuous organisms on the bottom of the habitat, excepting the much larger and more active blind prawns.

The most common animal found digging in the soft bottom sediments, and probably also the main food of the blind prawn, is a small red tubificid worm identified by Brinkhurst as Isochaeta israelis n. sp. (Brinkhurst, 1967). Other known species of the genus Isochaeta live in brackish water or in geologically old tectonic lakes as the Baikal, Tahoe or Dojran.

Three species of nematods were found in the sediment and identified by Andrássy (in letteris). Among them, Tripyloides marinus (Bütschli), a marine species which is sometimes found in continental salines; also Punctodora ochridensis W. Schneider which till now has been considered as an endemic species of Lake Ochrid - a tectonic lake, at least as old as Lake Tiberias (Por, 1963). The third species identified by Andrássy is Ironus ignavus Bastian.

The water above the bottom is inhabited by a rather dense population of the cyclopoid copepod Microcyclops minutus (Claus) which shows a certain loss of its eye pigmentation and probably represents a population morphologically segregated to a subspecies level.

Most interesting of all are perhaps the three species of malacostracan crustaceans discovered in the samples collected by the plankton nets. Parabathynella calmani Por, (1968) is the first syncarid found in Israel and in the Near and Middle East. The present species (Figure 2) is one of the evolved species of the genus: it is small $(1.3 \mathrm{~mm})$, the eighth thoracopode is reduced, as well as the antenna. As the supposed distribution boundary between Bathynella and Parabathynella is situated according to Noodt (1965) in southern Europe - the present finding may be considered as a confirmation of this view. However, serious doubts are raised about Noodt's (op. cit.) statement that the Bathynellacea had already completed their evolution by the beginning of the early Mesozoicum: the area under investigation was at that time still flooded by the Tethys. Another fact is the finding of this Parabathynella in a brackish spring. According to all the authors the Bathynellacea found till now are definitely freshwater stenohalines.

Monodella relicta Por (Figure 3) the fifth known thermosbenacean species appears also in En-Nur. Recently, this species was described from the warm mineral springs of En-Zohar on the western shore of the Dead Sea (Por, 
1962). This second locality and the obvious conspecificity of the two populations now prove that the whole Jordan system was a continuous marine gulf and that the isolation of the two populations is historically very young, probably post-pliocenic.

The ampiphod Bogidiella hebraea Ruffo (1963) previously found in the springs south of the Dead Sea has now also been found in En-Nur. The new finding of Bogidiella hebraea in this second locality confirms the above statement on the continuity of the Jordan system.

As only a relatively small part of the subterranean tract can be reached and observed by man, the faunistical and ecological picture drawn here is necessarily incomplete. However, although many problems remain open, and many answers are only suggested, the spring of En-Nur in the Tabgha group, doubtlessly holds a key position in the understanding of the history of the freshwater biota of Israel.

Octobre 1967

\section{ABSTRACT}

Exploration of the subterranean tract of the spring of En-Nur (at the north end of Lake Tiberias) by SCUBA diving and by use of new collecting methods, led to the discovery of a living community associated with the blind prawn Typhlocaris galilea.

A rich growth of sulphur bacteria and of pigmentless Cyanophyceae form the trophic basis in this peculiar biotope. Representatives of three hypogeic crustacean orders have been found as well as some peculiar gastropods, nematods and oligochaets. The latter are the main food of Typhlocaris galilea.

\section{RESUME}

L'exploration du cours souterrain du ruisseau de En-Nur (à l'extrémité nord du lac de Tibériade), en utilisant le système de plongée subaquatique Scuba et de nouvelles méthodes de récolte, a permis de découvrir une biocénose associéee à la crevette Typhlocaris galilea.

Des Bactéries sulfureuses et des Cyanophyceae apigmentées y sont florissantes et forment la base trophique de ce biotope particulier ou ont été rencontrés des représentants de trois ordres de Crustacés hypogés ainsi que des formes particulières de Gastéropodes, Nématodes et Oligochètes. Ces dernières constituent la nourriture principale de T. galilea.

\section{ACKNOWLEDGMENTS}

The authors' thanks are extended to Dr. E. Tchernov, from the Hebrew University, for the preliminary identification of the molluscs. Gratitude is expressed also to our colleagues Mrs. Z. Itzkowitz and Mr. D. Dagan, G. Raz, A. Gitay and A. Werechsohn for their help in different stages of this study.

\section{REFERENCES}

Annandale, N. (1912) - The Blind prawn of Galilee, Nature, London 90: 251 Annandale, N. and S. Kemp (1913) - The Crustacea Decapoda of the Lake of Tiberias. J. As. Soc. Bengal (N. S.) 9 (6): 241.258. 
BrinkHURst, R. (1967) - On some new species of aquatic Oligochaeta. Isr. J. Zool. (in press).

Calman, W. T. (1909) - On a blind prawn of the sea of Galilee (Typhlocaris galilea g. et sp. n.). Trans. Linn. Soc., Zool. 11 (2): 93-97.

NoodT, W. (1964) - Natürliches System und Biogeographie der Syncarida (Crustacea, Malacostraca). Gewässer u. Abwässer, 37-38: 77-186.

PoR, F. D. (1962) - Un nouveau Thermosbaenacee, Monodella relicta $\mathrm{n}$. sp. dans la depression de la Mer Morte. Crustaceana, 3/4, 304-310.

- (1963) - The relict aquatic fauna of the Jordan rift valley. Israel. J. Zool., 12/ $1-4: 47-58$.

- (1968) - Parabathynella calmani n. sp. (Syncarida, Bathynellacea) from Israel. Crustaceana 14/2, 151-154.

RufFo, S. (1963) - Studi sui Crostacei Anfipodi LVII. Una nuova specie di Bogidiella (Crustacea, Amphipoda) della depressione del Mar Morto. Bull Res. Counc. Israel $11 B / 4,188-195$.

Tsurnamal, M. - Observations on the Biology of the blind prawn Typhlocaris galilea Calman (Crustacea, Decapoda), in preparation.

\section{EXPLANATION OF PLAT 69 (1)}

Fig. 1a): Sketch map of Lake Tiberias and the Tabgha site; 1b) Schematical section through the subterranean flow of the spring of En-Nur (details, see text). Fig. 2: Parabathynella calmani Por from the spring of En-Nur. Fig. 3: Monodella relicta Por from the spring of En-Nur. 

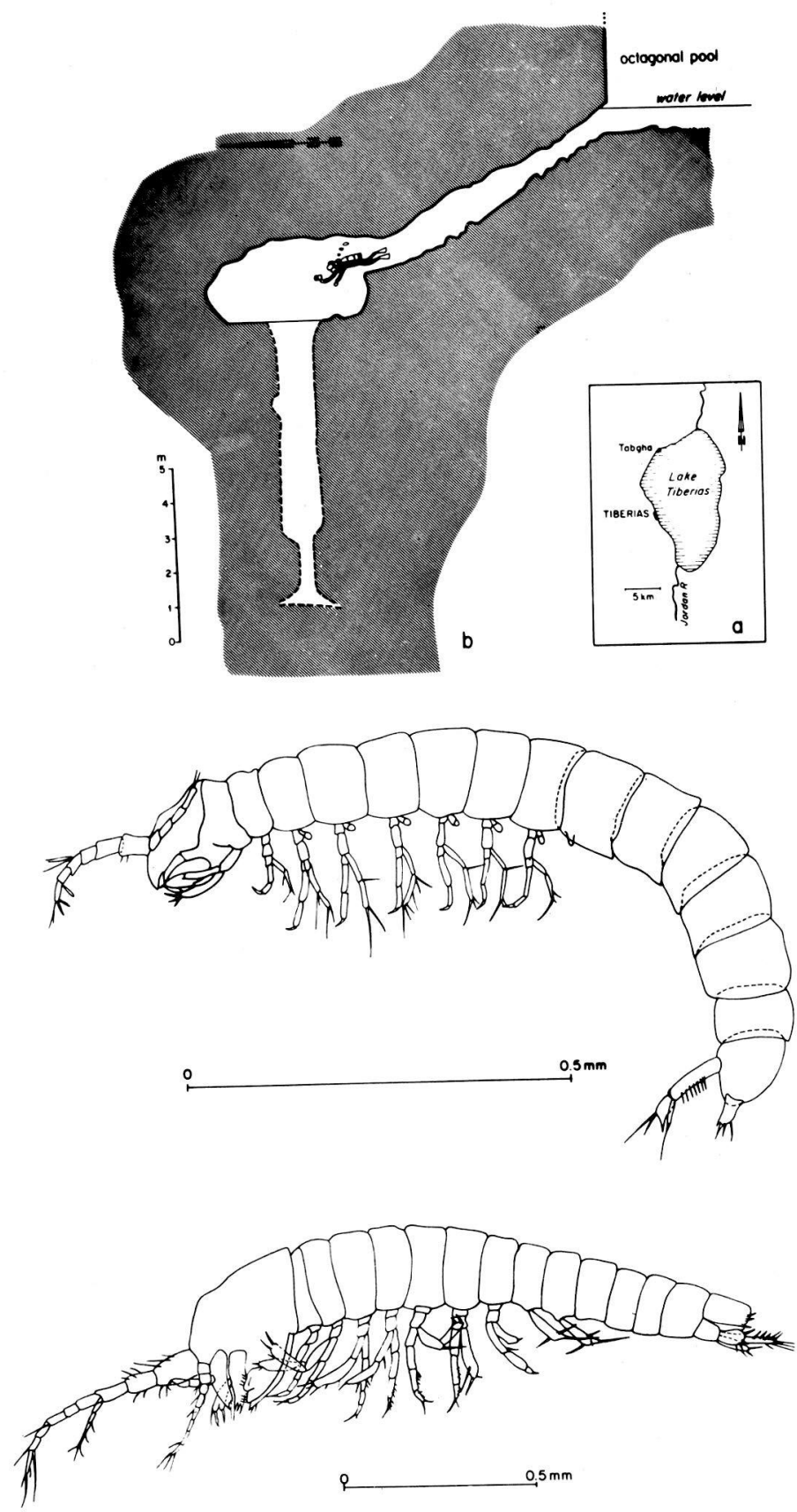